\title{
Wastewater Treatment Methods for Effluents from the Confectionery Industry - an Overview
}

\author{
Magdalena Zajda' ${ }^{1}$ Urszula Aleksander-Kwaterczak ${ }^{1 *}$ \\ 1 AGH University of Science and Technology, Faculty of Geology, Geophysics and Environmental Protection; al. \\ A. Mickiewicza 30, 30-059 Krakow, Poland \\ * Corresponding author's e-mail: aleksa@geolog.geol.agh.edu.pl
}

\begin{abstract}
Wastewater from the confectionery industry is characterized by daily and seasonal variability of composition and quantity which adversely affects the process of their disposal. Confectionery plants discharge about $300-500 \mathrm{~m}^{3}$ per month of technological wastewater. Sewage from the confectionery industry belongs to biologically degradable. It is characterized by high values of chemical oxygen demand (COD) and biological oxygen demand (BOD). The article reviews various methods used to treat wastewater from the confectionery industry. Attention was paid to the applicability of a particular method, its advantages and disadvantages and the costs of implementation. The technology of industrial wastewater treatment uses both mechanical and physicochemical methods as well as biological ones. Techniques of sewage treatment usually consist of several stages which use different processes. Low-cost materials such as natural minerals, agricultural waste, industrial waste, biosorbents, and others contribute to the improvement of aerobic sewage conditions. The main weakness of typical sewage treatment plants is their large area, high investment, and exploitation costs. Therefore, a good solution may be the use of the membrane biological reactor which combines the classical technique of activated sludge and filtration on micro-filtering membranes.
\end{abstract}

Keywords: confectionery industry, wastewater treatment, biological oxygen demand, chemical oxygen demand, low-cost material

\section{INTRODUCTION}

The confectionery industry is one of the most widespread and important industries around the world. It manufactures sweets including chocolate confectionery and gum products which are characterized by significant amounts of sugar and sugar substitutes, cocoa, fats, emulsifiers, and flavours used in the production process (Edwards 2000; El-kalyoubi et al. 2011; García-Morales et al. 2018).

The development of different industry branches has significantly improved people's quality of life in many aspects. However, industrial plants developing so numerously have started to emit a lot of water pollution (Próba and Wolny 2013). In many cases, sewage is discharged into rivers without any purification (Ntuli et al. 2011) which causes eutrophication, due to the high concentration of phosphorus and nitrogen (Demirel et al. 2005; Qasim and Mane 2013) and causes pollution of waters which could be used as a source of drinking water. The pollution of water caused by sewage input is a serious threat for people and animals (Elhassadi 2008).

Industrial waste consisting of a lot amount of organic compounds uses the oxygen dissolved in water to biochemical disintegration of these substances. The excessive oxygen usage by sewage may result in its total reduction in receiving water. This influences on generating anaerobic conditions which cause the extinction of aerobe and blocks the oxygen process of sewage self-cleaning. Water de-oxidation has also a bad influence on organisms living in the aquatic environment (Gromiec et al. 2014).

Water protection from industrial pollutions is one of the basic elements of sustainable 
development. In order to achieve this, it is necessary to purify the industrial wastewater more efficiently and to change the technologies to more friendly to the environment (Rajman 2007; Qasim and Mane 2013). A good method of controlling water pollution is the monitoring of industrial plants that discharge sewage directly to municipal channels. However, the task is often too expensive especially for largely industrialized regions (Ntuli et al. 2011). Quite often the costs that a production plant has to pay for the emission of poor quality sewage are very high. Therefore, factories are more and more often using different methods of sewage pretreatment.

The work reviews various methods used to treat wastewater from the confectionery industry. It was paid attention to the possibilities of using a particular method and its advantages and disadvantages.

\section{CHARACTERISTIC OF WASTEWATER FROM THE CONFECTIONERY INDUSTRY}

The main source of sewage in the confectionery industry is the cleaning process of the installation, so the amount of sewage generated depends on its frequency. For this reason, it is characterized by daily and seasonal variations in the composition and the quantity. This affects the process of its disposal. The confectionery plants discharge about $300-500 \mathrm{~m}^{3}$ per month of technological wastewater (Rucka et al. 2012). This sewage is biodegradable and it consists primarily of organic compounds and suspensions which affects the high values of chemical oxygen demand (COD) and biological oxygen demand (BOD) (Krzanowski et al. 2008). The COD index has usually values within the limits of $1000-12000 \mathrm{mg} \mathrm{O}_{2} / \mathrm{L}$, while $\mathrm{BOD}_{5}$ up to 500-8000 $\mathrm{mg} \mathrm{O}_{2} / \mathrm{L}$ (Table 1). The organic substances that are contained in wastewater are mainly sugars, fats, and dyes (Colic et al. 2009; Esparza-Soto et al. 2013; García-Morales et al. 2018; Rucka et al. 2012; Qasim and Mane 2013). Confectionery sewage often contains solutions for washing and disinfecting agents too, which can cause changing the $\mathrm{pH}$ value and increasing the content of nitrogen and phosphorus compounds (Krzanowski et al. 2008).

\section{WASTEWATER TREATMENT METHODS}

The treatment of wastewater is a relatively modern practice. The first mechanical and biological processes designed to treat municipal wastewater emerged early by the end of the $19^{\text {th }}$ century (Environmental Protection Agency 1997).

The technology of industrial wastewater treatment uses both mechanical and physicochemical methods as well as biological ones (Figure 1) (Bhargava 2016).

\section{Mechanical treatment}

Mechanical wastewater treatment, this socalled first stage of purification, are intended to eliminate larger floating and dragged solids, granular particles with a diameter greater than $0.1 \mathrm{~mm}$, and easily falling suspensions, oils and fats. This is achieved through the use of grates and screens that trap and separate solid objects

Table 1. The main properties of sewage from the exemplary confectionery plants

\begin{tabular}{|c|c|c|c|c|c|c|c|}
\hline Kind of industry & $\begin{array}{c}\mathrm{BOD} \\
{\left[\mathrm{mg} \mathrm{O}_{2} / \mathrm{L}\right]}\end{array}$ & $\begin{array}{c}\mathrm{COD} \\
{\left[\mathrm{mg} \mathrm{O}_{2} / \mathrm{L}\right]}\end{array}$ & $\begin{array}{c}\mathrm{EC} \\
{[\mu \mathrm{S} / \mathrm{cm}]}\end{array}$ & $\begin{array}{c}\mathrm{pH} \\
-\end{array}$ & $\begin{array}{l}\mathrm{NH}_{4}^{+}-\mathrm{N} \\
{[\mathrm{mg} / \mathrm{L}]}\end{array}$ & $\begin{array}{l}\text { P total } \\
{[\mathrm{mg} / \mathrm{L}]}\end{array}$ & Literature \\
\hline $\begin{array}{l}\text { Candy manufacturing plant } \\
\text { in Mexico }\end{array}$ & 8000 & 2500 & - & - & - & - & Colic et al. (2009) \\
\hline $\begin{array}{l}\text { Chocolate manufacturing } \\
\text { industry in Mexico }\end{array}$ & - & 3608 & 750 & 7.4 & - & - & $\begin{array}{l}\text { García-Morales } \\
\text { et al. (2018) }\end{array}$ \\
\hline $\begin{array}{l}\text { Confectionery plants in } \\
\text { Poland }\end{array}$ & 5400 & 10,996 & 633 & 4.1 & 28.5 & 13.2 & Rucka et al. (2014) \\
\hline $\begin{array}{l}\text { Food industries (dairy } \\
\text { effluent, sweet-snacks and } \\
\text { ice-cream), India }\end{array}$ & $442-523$ & $8960-11,900$ & $794-1082$ & $5.6-7.1$ & $89-120$ & $78-157$ & $\begin{array}{l}\text { Qasim and Mane } \\
(2013)\end{array}$ \\
\hline $\begin{array}{l}\text { Food processing industry } \\
\text { in India }\end{array}$ & 6860 & 11,220 & - & $4.1-4.3$ & - & 3.2 & $\begin{array}{l}\text { Vanerkar et al. } \\
(2013)\end{array}$ \\
\hline Sugar industry, Ethiopia & - & 3682 & - & 5.5 & - & 5.9 & Sahu (2017) \\
\hline $\begin{array}{l}\text { Confectionery factory - } \\
\text { sugar line, Turkey }\end{array}$ & - & 20,025 & 680 & 3.8 & - & - & Ozgun et al. (2012) \\
\hline Sugar industry, Pakistan & 3132 & 12,211 & - & 9.5 & - & - & Khan et al. (2003) \\
\hline
\end{tabular}

Note: - not determined. 


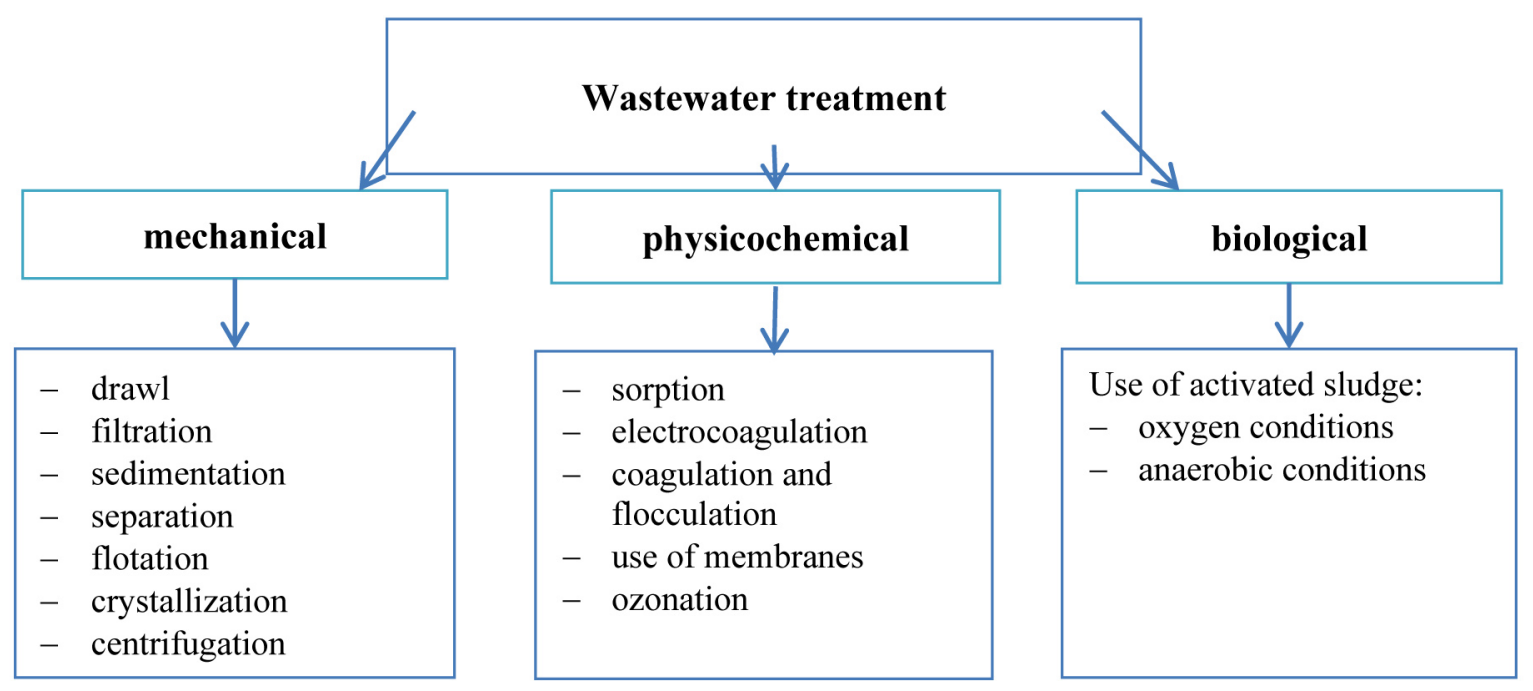

Fig. 1. Wastewater treatment methods

from the bulk wastewater. At this stage, processes such as filtration, drainage, sedimentation and flotation take place. As a result, the content of organic compounds in wastewater can be reduced by a few percents (Bartkiewicz and Umiejewska 2010).

\section{Physicochemical treatment}

\section{Sorption}

The process of sorption includes two phenomena. The first of them is adsorption, which involves the attachment of molecules on the surface of a solid or liquid. The second is the absorption consisting of the sorption of one substance by another forming any continuous phase. Methods using the adsorption process is considered as one of the most competitive because they are not complicated and do not require high operating temperature (Hashemian et al. 2014).

Activated carbon is a material that adsorbs organic compounds very well (Dakhil 2013). This is due to its large surface area, porosity and resistance to chemical and thermal changes (El-Dars et al. 2014). For this reason, it is the most versatile adsorbent used in the wastewater treatment process. It reduces BOD and COD values by more than 90\% (Devi et al. 2008; Nayl et al. 2017; Sanou et al. 2016; Yamina et al. 2013). The main disadvantage of its use is the high cost of production (El-Dars et al. 2014) and regeneration as well as disposal problems. That's why scientists search for the cost-effective and more environmentallyfriendly sorbents with similar properties as carbon (Carvalho et al. 2011).
The ideal adsorbents should be solids with a large surface area, porosity, inertness, and good physical and chemical properties (Paprowicz 1990; Parande et al. 2009). As low-cost adsorbents natural minerals (bentonite, kaolinite, zeolites, silica beads), agricultural waste (eggshells, corn cobs, chicken feathers, rice husks, coconut shells), industrial by-products, biosorbents (chitosan, peat, biomass) and others (e.g. starch, cyclodextrin, cotton) were tested (Al-Jlil 2009; Ariffin et al. 2017; Carvalho et al. 2011; Parande et al. 2009). It was found that also such elements as wool, sawdust, cocoa shell, sugar beet pulp, distillery sludge or maple saw dust can be effective in metals reduction and the improvement of aerobic conditions in wastewater. Furthermore, metakaolin and carbon made from dates nuts and tamarinds in the condition of neutral $\mathrm{pH}$ can significantly improve the oxygen conditions in wastewater with a high content of organic compounds (Parande et al. 2009). It was also demonstrated that a perfect absorbent is an active carbon produced from almond shells and orange peels wastes (Hashemian et al. 2014).

It was observed that active carbon produced by activation with phosphoric acid $\left(\mathrm{H}_{3} \mathrm{PO}_{4}\right)$ from olive stones has a very well developed pore structure, which will result in the high level of pollution sorption (Yakout and Sharaf El-Deen 2016). The low-cost absorbents as coconut tree sawdust, silk cotton hull, sago waste, maize cob, and bananas were also used from preparation an active carbon. It was generated to remove high-density metals and dyes from water solution. The results of the experiment prove that all kind of carbon 
was effective in the removal of pollution from water (Henze et al. (Eds.) 2008).

Qasim and Mane (2013) conducted experiments of clearing the sewage coming from the production of sweets and ice cream with the usage of powdered activated charcoal as absorbent. They proved that such kind of carbon can significantly improve oxygen conditions of sewage. It was also showed that biological wastes from squid processing can reduce BOD values by 90 95\% (Park et al. 2001).

The advantages and disadvantages of the adsorption process in the BOD and COD reduction are presented in Table 2 .

\section{Coagulation and flocculation}

In wastewater treatment, these methods are mainly used to remove suspended solids and organic compounds. The effectiveness of processes depends on the selection of suitable coagulant. The most popular are aluminium and iron salts as well as active silica (Bhargava 2016). In the case of wastewater from the food industry, the use of ferrous sulphate as a coagulant can cause a reduction of BOD from about $33 \%$ to $58 \%$ and COD from about $30 \%$ to $53 \%$. While the use of limes led to slightly larger improvement aerobic conditions (BOD: 34\%-66\% and COD 32\%-59\%) (Vanerkar et al. 2013).

Vanterkar et al. (2013) conducted an experiment in which they used as a coagulant: lime, alum, ferrous sulphate or ferric chloride in combination with different polyelectrolytes as lime $200 \mathrm{mg} / \mathrm{L}+$ anionic-synthetic polyelectrolyte (Magnafloc - E-207), lime $200 \mathrm{mg} / \mathrm{L}+$ nonionic - synthetic polyelectrolyte (Zetag - 7650) and lime $300 \mathrm{mg} / \mathrm{L}$ + cationic - synthetic polyelectrolyte (Oxyfloc - FL-11). The analysis showed that $0.3 \mathrm{mg} / \mathrm{L}$ Magnafloc E-207 in combination with the optimal dose of lime $200 \mathrm{mg} / \mathrm{L}$, was very effective in the reduction of COD - $67.6 \%$ and BOD - $71.0 \%$.

The widely available and economical materials as lime, alum, polymer, and dried leaves were also tested as coagulants for the reduction of BOD and phosphorus in wastewater after biological treatment. It has been shown that the materials do not change the $\mathrm{pH}$ but has contributed to a significant reduction of the phosphorus concentration and BOD ratio up to $80-90 \%$ (Mortula et al. 2011). Good coagulants can also be organic compounds, e.g. "chitosan", which comes from shells of some crustaceans. They could be used to remove organic matter that causes high BOD levels (Bough 1976). The advantage of this natural substance is the ability to recover sediment (Table 3) (Park et al. 2001).

\section{Electrocoagulation}

Electrocoagulation (EC) is an electrochemical technology increasingly used in wastewater treatment (Mollah et al. 2001; Mollah et al. 2004; Sahu et al. 2014). The EC is simple and efficient process in which iron or aluminium anodes that are electrolytically dissolved are commonly used (Akbal and Camc1 2011; Mollah et al. 2004). The production of the coagulating agent is carried out in situ by electro-oxidation of a sacrificial anode and there is no need to add any chemical coagulants or flocculants (Keshmirizadeh et al. 2011; Thirugnanasambandham et al. 2013).

Investigation of wastewater from the sugar industry using electrocoagulation with zinc electrodes in a bipolar system shows a significant reduction of COD (81\%), BOD (89\%) and total solids content (90\%) (Byadgi et al. 2017). While treatment using an electrochemical process with hybrid iron and aluminium electrodes resulted in

Table 2. The advantages and disadvantages of the adsorption process in the wastewater treatment technology (according to Ariffin et al. 2017; Park et al. 2001)

\begin{tabular}{|l|l|}
\hline \multicolumn{1}{|c|}{ Advantages } & \multicolumn{1}{c|}{ Disadvantages } \\
\hline$-\quad \begin{array}{l}\text { large BOD and COD reduction } \\
-\end{array}-\begin{array}{l}\text { easy-to-use } \\
-\end{array}$ cheap technology & - adsorbent loses its effectiveness over time \\
\hline
\end{tabular}

Table 3. The advantages and disadvantages of the coagulation and flocculation processes in wastewater treatment technology (according to Ariffin et al. 2017; Mortula et al. 2011; Park et al. 2001)

\begin{tabular}{|l|l|}
\hline \multicolumn{1}{|c|}{ Advantages } & \multicolumn{1}{c|}{ Disadvantages } \\
\hline- good BOD and COD reduction \\
- cheap technology using natural coagulants & - large amount of sediment generated \\
\hline
\end{tabular}


the reduction of COD by $90 \%$ and of the colour by $93.5 \%$ (Sahu 2017). The integrated electrocoagulation process using aluminium sacrificial anodes and the sand filtration process as a pretreatment of wastewater from the chocolate allowed reducing turbidity, colour and COD by about $96 \%, 98 \%$ and $39 \%$, respectively. What is more, hybrid electrodes are safe to operate and economical (García-Morales et al. 2018).

An analysis of the clearing effectiveness of artificial wastewater from milk powder by the electrocoagulation method using the aluminum anode showed a significant decrease of turbidity, total phosphorus and nitrogen. The effectiveness of COD reaches only $61 \%$. While, the chemical coagulation with aluminium sulphate contributed to the improvement of turbidity and nitrogen, but the effectiveness of phosphorous reduction, as well as COD, was slightly higher. The advantage of electrocoagulation over coagulation is because the electrocoagulation process uses fewer reagents and the wastewater treated by electrocoagulation has lower conductivity and neutral $\mathrm{pH}$ value, which allows recycled treated water for some industrial applications (Tchamango et al. 2010).

The wastewater treatment experiment using electrocoagulation with aluminum electrodes was also performed on wastewater from the production of sweets and ice cream. After electrocoagulation, the reduction of turbidity reached $100 \%$, phosphorous of $89 \%$ and COD index reduced by $61 \%$, indicating that this technique is the best and more efficient in treating such type of effluents (Qasim and Mane 2013). Other scientists used electrocoagulation with the same kind of electrode to separate pollutants from the restaurant wastewater. The analysis showed that the electrodes effectively remove organic compounds and can neutralize the $\mathrm{pH}$ of sewage (Chen et al. 2000). It was indicated that the $\mathrm{pH}$ plays an important role in determining the removal efficiencies of the electrocoagulation process, and the removal of the COD parameter increases with increasing of $\mathrm{pH}$ to 6.5 (Thirugnanasambandham et al. 2013).

However, the initial capital expenditures and projected operating costs of the electrocoagulation process in wastewater treatment are high and are estimated at USD 140,000 and USD 40,000/ year, respectively (Tab. 4) (Park et al. 2001).

\section{Ozonation}

Ozone is a strong oxidant and is easily soluble in water, therefore it is used in the wastewater treatment processes. Ozonation is most effective for well-diluted wastewater. In wastewater with a high concentration of organic compounds, this process can only be used as a preliminary phase in the entire treatment technology (https://www. ozonetech.com).

The experiment involving the oxidation of raw sewage from the confectionery industry using ozone was carried out by Benincá et al. (2013). It was performed in a semi-batch reactor at the temperature of $20^{\circ} \mathrm{C}$ for two hours and an ozone mass flow rate of $1.158 \times 10^{-6} \mathrm{~kg} / \mathrm{s}$. At such condition, a total decrease of TOC was no higher than $60 \%$ and a reduction in the colour of the raw wastewater to almost $10 \%$ was noticed.

Table 4. The advantages and disadvantages of the electrocoagulation process in wastewater treatment technology (according to Ariffin et al. 2017; Park et al. 2001)

\begin{tabular}{|l|l|}
\hline \multicolumn{1}{|c|}{ Advantages } & \multicolumn{1}{|c|}{ Disadvantages } \\
\hline- minimal chemical additives & - relatively low reduction of high BOD and COD values \\
$-\quad$ low sludge production & - electrodes require to be regular exchange \\
$-\quad$ large reduction suspensions and colour & - high operating and maintenance costs \\
$-\quad$ simple equipment required & \\
$-\quad$ easy operation and automation & \\
$-\quad$ short retention time & \\
\hline
\end{tabular}

Table 5. The advantages and disadvantages of the ozonation process in wastewater treatment technology (according to US EPA 1999)

\begin{tabular}{|l|l|}
\hline \multicolumn{1}{|c|}{ Advantages } & \multicolumn{1}{c|}{ Disadvantages } \\
\hline$-\begin{array}{l}\text { lack of harmful waste } \\
-\quad \begin{array}{l}\text { short time of wastewater contact with ozone } \\
(15-20 \text { minutes })\end{array}\end{array}$ & - weak reduction of high BOD and COD values \\
\hline
\end{tabular}


The investment costs were estimated at USD 190,000 and annual operating costs at USD 40,000 (Park et al. 2001) (Table 5).

\section{The use of membranes}

Membranes can be considered as selective barriers, allowing the passage of certain constituents from the mixture and retaining others. The driving force of transport is the gradient of some potential, such as pressure, temperature, concentration or electrical potential (Mai 2014). One of the particular advantages of this process is that it relies on physical separation, usually without the addition of chemicals. The most popular membrane treatment technologies are pressure processes that are divided into microfiltration, ultrafiltration, nanofiltration and reverse osmosis (Van der Bruggen et al. 2003). Table 6 shows the relationships between the type of membrane, pore size, type of process, and retained contaminants.

The membrane test was used to treat wastewater from the calamari processing line with a very high BOD value $(1000-5000 \mathrm{mg} / \mathrm{L})$. The first stage of the experiment showed that the single-stage test using ultrafiltration membrane (UF) did not reduce BOD effectively because proteins and other organic substances passed through the membrane. The permeate from the first stage was directed to the nanofiltration membrane (NF). This caused the reduction of the BOD to about 300 $\mathrm{mg} / \mathrm{L}$. In the two-stage system, the BOD indicator decreased by over $90 \%$ (Park et al. 2001). Ultrafiltration and nanofiltration membranes were also used for the treatment of wastewater from restaurants which served typically Malay foods. Depending on membrane type, very high reduction of COD (up to $97.8 \%$ ) and turbidity $(99.9 \%$ ) and strongly removal of BOD5 (86.8\%) and conductivity $(82.3 \%)$ were found. The restaurant owner may have the additional benefit of reusing treated wastewater for non-drinking purposes (Zulaikha et al. 2013). The disadvantage of membrane systems is that there is about $75 \%$ water recovery which means that about $25 \%$ of the leachate remains (Table 7).

\section{Biological methods}

\section{The use of activated sludge}

Wastewater treatment with activated sludge under aerobic conditions is one of the most commonly used technologies (Henze et al. (Eds.) 2008; Scholz 2016) but costs associated with the purchase and operation can be often too high for industrial applications (Park et al. 2001). The activated sludge is a biological system in which both physical processes and biochemical reactions take place. Macroscopically, it is a suspension consisting of flocculating agglomerations of heterotrophic bacteria. Physical processes occur on the surface of flocks, which are based on the adsorption of organic compounds and as a result

Table 6. Characteristics of membranes (according to Ratajczak 2013)

\begin{tabular}{|c|c|c|c|c|}
\hline Process: & Microfiltration & Ultrafiltration & Nanofiltration & Reverse osmosis \\
\hline Emulsion, Colloids, Bacteria & & & & \\
\hline \multicolumn{5}{|l|}{ Proteins, Viruses } \\
\hline \multicolumn{5}{|l|}{ Dye } \\
\hline \multicolumn{5}{|l|}{ Polyvalent ions } \\
\hline \multicolumn{5}{|l|}{$\begin{array}{l}\text { Monovalent cons } \\
\text { Simple carbohydrates }\end{array}$} \\
\hline Pressure range [MPa] & $0.1-0.3$ & $0.3-1.0$ & $0.5-3.0$ & $2.0-5.0$ \\
\hline Membrane construction & symmetrical, porous & asymmetric, porous & $\begin{array}{l}\text { asymmetric, } \\
\text { composite }\end{array}$ & $\begin{array}{c}\text { asymmetric, } \\
\text { composite }\end{array}$ \\
\hline Pore size & $0.05-10 \mu \mathrm{m}$ & $0.01-0.05 \mu \mathrm{m}$ & $1.00-8.00 \mathrm{~nm}$ & solid \\
\hline $\begin{array}{l}\text { Approximate size of } \\
\text { separated molecules }\end{array}$ & $0.1 \mu \mathrm{m}$ & $2.0-20.0 \mathrm{~nm}$ & $0.001 \mu \mathrm{m}$ & $0.0001 \mu \mathrm{m}$ \\
\hline
\end{tabular}

Table 7. The advantages and disadvantages of the membrane in wastewater treatment technology (according to Park et al. 2001)

\begin{tabular}{|l|l|}
\hline \multicolumn{1}{|c|}{ Advantages } & \multicolumn{1}{c|}{ Disadvantages } \\
\hline- lack of chemical additives & - leachates with a high concentration of pollutants \\
- high reduction of BOD and COD using multi-stage systems & - high operating and maintenance costs \\
\hline
\end{tabular}


they decompose into smaller fragments. They are then absorbed by the microbial cells in which they undergo a further transformation. Bacteria in the activated sludge produce enzymes that catalyse the series of biochemical reactions, resulting in decomposition of inorganic and organic compounds in wastewater (Scholz 2016). Wastewater treatment using activated sludge was used in many confectionery plants.

El Diwani et al. (2000) designed an integrated pilot plant consisting of an equalizer, a chemical mixer, an aerator, a clarifier, a disinfectant tank, and a sand filter for wastewater treatment from the production of gums and sweets. After the purification process, the BOD index decreased from $3200 \mathrm{mg} / \mathrm{L}$ to $70 \mathrm{mg} / \mathrm{L}$ and the COD from $5000 \mathrm{mg} / \mathrm{L}$ to $100 \mathrm{mg} / \mathrm{L}$. Experiments of wastewater treatment by the activated sludge were also carried out in the laboratory conditions using in the periodic operation reactors (SBR). Three reactors worked in two cycles per day and included the aeration and sedimentation phase. The results of the analysis showed over $95 \%$ efficiency of COD and BOD removal. The values of these indexes in treated wastewater were significantly lower than the admissible values for sewage entering into the sewage system (Rucka et al. 2014).

The main disadvantage of the described technologies is too high costs, the complicated technique and extinction of compacted bacteria in the activated sludge (Park et al. 2001) (Table 8).

\section{Treatment under anaerobic conditions}

Anaerobic treatment is based on a microbiological process, such as methane fermentation, during which properly selected bacterial strains to convert organic waste contained in sewage into biogas (methane and $\mathrm{CO}_{2}$ ). The bacteria involved in the process are found in anaerobic sludge: flocculent and granular.
Many methods of wastewater treatment are carried out based on anaerobic technologies. Anaerobic digestion was used to treat not only for many types of waste but also biosolids (Amani et al. 2010; Park et al. 2001). The Up-flow Anaerobic Sludge Blanket (UASB) reactor has become very popular in recent years and has been widely used for the treatment of various kinds of wastewater (Seghezzo et al. 1998). The advantages of using this reactor result from high removal efficiency even at low temperature, low energy consumption and low space requirements. It is very useful in the treatment of organic wastewater due to the high biomass concentration and rich microbial diversity (Liu et al. 2003).

Tanksali (2013) treated wastewater from a sugarcane factory in the UASB reactor with nongranular anaerobic activated sludge at the temperature of $26-39^{\circ} \mathrm{C}$ under the laboratory conditions. It was obtained the high COD removal efficiency ranged from $80 \%$ to $96 \%$, while the maximum volume of biogas production was $13.72 \mathrm{~L} / \mathrm{d}$ and the methane concentration in biogas was $71 \%$. The same reactor was tested by Atashi et al. (2010) for treatment the influent from the sugar factory. The best level of COD values reduction that they obtained was $90 \%$ at $\mathrm{pH}=7$ and temperature of $35-38^{\circ} \mathrm{C}$.

Park et al. (2001) conducted a pilot treatment of sewage from the squid processing. $\mathrm{He}$ obtained a BOD reduction by about $80 \%$. The capital equipment costs of this technology were estimated at USD 490,000 and operating costs at USD 45,000 per year (Table 9).

\section{DISCUSSION}

Many confectionery plants struggle a serious problem concerning the quality of industrial wastewater. The confectionery industry contributes a large extend to the generation of wastewater

Table 8. The advantages and disadvantages of the activated sludge under aerobic conditions in the wastewater treatment technology (according to Park et al. 2001)

\begin{tabular}{|l|l|}
\hline \multicolumn{1}{|c|}{ Advantages } & \multicolumn{1}{c|}{ Disadvantages } \\
\hline - lack of odours & - complicated technique \\
- high reduction of BOD and COD & - high operating costs \\
& - formation of a large amount of sludge \\
& - sudden increase in volume or change in the composition \\
& of sewage may have a negative effect on the operation of \\
& the process
\end{tabular}


Table 9. The advantages and disadvantages of the biological treatment under anaerobic conditions in the wastewater treatment technology (according to Park et al. 2001)

\begin{tabular}{|l|l|}
\hline \multicolumn{1}{|c|}{ Advantages } & Disadvantages \\
\hline- possibility of energy recovery & - high operating and maintenance costs \\
- high reduction of BOD and COD & - considerable sensitivity of methanogenic bacteria to \\
- low sludge production compared to oxygen methods & - need for expansion tanks \\
\hline
\end{tabular}

with a high content of organic compounds (sugars, fats, proteins) which result in the increase of the BOD and COD indices. Industrial wastewater is generated as a result of cleaning the installation due to which they are characterized by significant quantitative and qualitative volatility. To limit and control the emission of pollutants into the environment, most countries have introduced various legal acts regulating the quality and quantity of discharges of pollutants (Ntuli et al. 2011). The Council Directive 91/271/EEC applies to the countries of the European Union concerning the treatment of municipal wastewater. Its purpose is to protect the environment against the adverse effects of municipal sewage discharges from some of the industrial sectors (91/271/EEC). On the other hand, wastewater re-use standards have been introduced in the Eastern Mediterranean (CEHA 2006).

Due to the growing limitations of environmental standards, confectionary plants incur huge costs associated with non-compliance. For this reason, such plants are looking for an optimal in terms of the environmental and economic method of treating sewage.

Various methods have found, to a greater or lesser extent, their application in the treatment of wastewater from the confectionery industry. The selection of methods is influenced above all by the efficiency of treatment and economic aspects. In order to obtain the best efficiency and complementarity of wastewater treatment, techniques that consist of several stages and different processes are used. The integrated process can be an attractive alternative to the initial treatment of wastewater to improve the quality of water in conventional treatment methods or it can be used as a pre-treatment of wastewater (García-Morales et al. 2018).

The multi-phase sewage treatment process was presented by Al-Jlil (2009). He conducted research to improve the quality parameters of domestic sewage using sedimentation, aeration, sand filtration, active carbon, and chlorination. The study showed that by applying the different physicochemical and biological processes, the reduction of BOD and COD reached 92.2\% and $97.7 \%$, respectively. Yamina et al. (2013) showed that initial physicochemical methods can improve the oxygenic conditions of wastewater. They used a bi-layer filtration system consisting of a mixture of active carbon and sand dune. As a result, rates of BOD and COD reduced by $99 \%$ and $98 \%$, respectively.

Ozgun et al. (2012) also presented a multistage scheme of sewage treatment which comes from different production lines in the confectionery industry generated about $170,000 \mathrm{~m}^{3} /$ year of wastewater. The system of wastewater treatment consisted of screens, equalization tanks, dissolved air flotation, an anaerobic expanded granular sludge bed reactor (EGSB), and a conventional activated sludge system with the sludge treatment line. The research proved that the reduction of COD in an anaerobic reactor reached $88 \%$, while the use of the anaerobic reactor led to a decrease in COD by $95 \%$. It is promoted the use of anaerobic technology as a pre-treatment before conventional oxygen treatment.

The combination of biological aerobic and anaerobic processes was also used in sewage treatment plants in Tymbark fruit processing in Poland. The technological line consisted of the following stages: sewage pre-treatment on the grate, grate and sieve to retain solids, biological aerobic and anaerobic treatment and separation of suspensions in the process of flotation under pressure The use of aerobic and anaerobic reactors involves many benefits, such as a positive energy balance, reduced sludge production and space-saving. An additional advantage is a possibility of using biogas which is generated during anaerobic processes, as fuel in the factory boiler room which is extremely beneficial in terms of sewage exploitation costs (http://www.veoliawatertechnologies.pl).

The assessment of the effectiveness of COD, turbidity and colour removal was also carried out during the integration of the electrocoagulation process using aluminium anodes and the sand 
filtration process as pre-treatment of sewage from the chocolate manufacturing plant in Mexico. In the integrated process, the decrease of turbidity by $96 \%$ has appeared. Whereas the disposal of colour and COD reached $98 \%$ and 39\%, respectively (García-Morales et al. 2018).

The main weakness of typical sewage treatment plants is their large area, high investment and exploitation costs. A good solution, in this case, can be the use of a membrane biological reactor (MBR). It combines the classical technique of activated sludge and pressure membrane methods. The membrane is an absolute barrier to suspended matter and microorganisms. Its advantage, compared with traditional methods of sewage treatment, is the total separation of solids by ultra-filtration, the possibility of reuse of treated sewage, high concentration of activated sludge and low operating costs (Cicek 2003; Fazal et al. 2015; Judd 2006; Lin et al. 2012; Marrot et al. 2004).

The effectiveness of wastewater treatment using the MBR systems was tested in the case of sewage from the field crop processing, seafood, the dairy and the winery industry. In treated sewage, in high removal of basic pollution can be observed (COD usually $>90 \%$ ). Phuong et al. (2018) tested the effectiveness of wastewater treatment from a cake shop using a Submerged Membrane Bioreactor with a hollow fibre membrane. The experiment confirmed that the integrated MBR system removes organic compounds from sewage successfully.

Therefore, there are many different methods of wastewater treatment from the food industry, which can be selected in an optimal way for a given object. It is very important to be guided not only by economic criteria but also by environmental ones.

\section{CONCLUSIONS}

The sewage coming from the confectionery industry is characterized by daily and seasonal variability of composition and quantity which adversely influences the process of their neutralization. The wastewater features are high values of oxygen indicators - BOD and COD. Methods of the sewage treatment use various processes, both mechanical and physicochemical as well as biological ones. Each of them has its pros and cons.

Mechanical methods are used as a preliminary stage of wastewater treatment. They contribute to reducing organic compounds by several percents. The adsorption process on the natural sorbents causes a high decrease of BOD and COD but the disadvantage of this technique is the problem of waste disposal. Coagulation and flocculation are not good methods for the discussed wastewater, because it only partly reduces BOD as well as COD and its main disadvantage is the production of a huge amount of waste. Electrocoagulation contributes to a significant reduction of oxygen indicators and it does not require chemical additives. However, membrane techniques using multi-stage systems, although they are characterized by a high reduction of BOD and COD, have some disadvantages. It is high exploitation costs and the formation of leachates with a large waste concentration. Both aerobic and anaerobic processes of activated sludge cause a decrease in the content of organic compounds in sewage. However, uneven sewage inflow can lead to degradation of the activated sludge. These techniques are therefore often unprofitable for the confectionery industry.

The main drawback of classic wastewater treatment plants is their large area, high investment and operating costs. That is why MBR Membrane Biological Reactor has become very popular. It combines the classical technology of activated sludge with filtration on microfiltration membranes.

\section{Acknowledgments}

The work was financed as part of the statutory tasks of the AGH University of Science and Technology in Krakow - 11.11.140.017.

Magdalena Zajda has been partly supported by the EU Project POWR (Programu Operacyjnego Wiedza Edukacja Rozwój) - 03.02.00-00-I038/16-00

\section{REFERENCES}

1. Akbal F., Camc1 S., 2011. Copper, chromium and nickel removal from metal plating wastewater by electrocoagulation. Desalination, 269, 214-222.

2. Al-Jlil S.A., 2009. COD and BOD reduction of domestic wastewater using activated sludge, sand filters and activated carbon in Saudi Arabia. Biotechnology, 8, 473-477.

3. Amani T., Nosrati M., Sreekrishnan T.R., 2010. Anaerobic digestion from the viewpoint of microbiological, chemical, and operational aspects - a review. Environmental Reviews, 18, 255-278. 
4. Ariffin N., Abdullah M.M.A.-B., Zainol M.R.R.M.A., Murshed M.F., Zain H., Faris M.A., Ridho B., 2017. Review on adsorption of heavy metal in wastewater by using geopolymer. MATEC Web of Conferences, 97, 1-8.

5. Atashi H., Ajamein H., Ghasemian S., 2010. Effect of operational and design parameters on removal efficiency of a pilot-scale UASB reactor in a sugar factory. World Applied Sciences Journal, 11(4), 451-456.

6. Bartkiewicz B., Umiejewska K., 2010. Treatment of industrial wastewater. PWN, Warszawa (in Polish).

7. Benincá C., Peralta-Zamora P., Tavares C.R.G., Igarashi-Mafra L., 2013. Degradation of an azo dye (Ponceau 4R) and treatment of wastewater from a food industry by ozonation. Ozone Science and Engineering, 35(4), 295-301.

8. Bhargava A., 2016. Physico-chemical waste water treatment technologies: an overview. International Journal of Scientific Research and Education, 4, 2321-7545.

9. BOD \& COD treatment with ozone. https://www. ozonetech.com/water-treatment/cod-bod-treatment-ozone. Accessed 11 November 2018.

10. Bough W.A., 1976. Chitosan - a polymer from seafood waste, for use in treatment of food processing wastes and activated sludge. Process Biochemistry, 11(1), 13-16.

11. Construction of a factory sewage treatment plant for Tymbark in Olsztynek. http://www.veoliawatertechnologies.pl/media/case_studies_Veolia/ oczyszczalnia_sciekow_Tymbark_Olsztynek.htm. Accessed 08 January 2019 (in Polish).

12. Byadgi S.A., Sharanappanavar M.S., Dhamoji B., Nadaf A., Munennavar S., 2017. Treatment of sugar industry waste water using zinc electrodes. International Journal of Engineering Technology Science and Research, 4(6), 664-668.,

13. Carvalho J., Araujo J., Castro F., 2011. Alternative low-cost adsorbent for water and wastewater decontamination derived from eggshell waste: an overview. Waste Biomass Valor, 2, 157-167.

14. Chen X., Chen G., Yue P.L., 2000. Separation of pollutants from restaurant wastewater by electrocoagulation. Separation and Purification Technology, 19, 65-76.

15. Cicek N., 2003. A review of membrane bioreactors and their potential application in the treatment of agricultural wastewater. Can. Biosyst. Eng., 45(6), 37-49.

16. Colic M., Acha E., Lechter A., 2009. Advanced pretreatment enables MBBR treatment of high strength candy manufacturing wastewater. Proceedings of the Water Environment Federation, WEFTEC: Session 61 through Session (11), 70, 4142-4152.
17. Dakhil I.H., 2013. Adsorption of methylene blue dye from wastewater by spent tea leaves. Journal of Kerbala University, 1, 5-14.

18. Demirel B., Yenigun O., Onay T.T., 2005. Anaerobic treatment of dairy wastewaters: a review. Process Biochemistry, 40(8), 2583-2595.

19. Devi R., Singh V., Kumar A., 2008. COD and BOD reduction from coffee processing wastewater using avocado peel carbon. Bioresource Technology, 99, $1853-1860$.

20. Directive 91/271/EEC of 21 May 1991 concerning urban waste-water treatment (91/271/EEC).

21. Edwards W.P., 2000. The science of sugar confectionery. The Royal Society of Chemistry. Cambridge, UK, 1-222.

22. El Diwani G., El Abd H., Hawash S., El Ibiari N., El Rafei S., 2000. Treatment of confectionery and gum factory wastewater effluent. Adsorption Science \& Technology, 18(9), 813-821.

23. El-Dars F.M.S.E., Ibrahim M.A., Gabr A.M.E., 2014. Reduction of COD in water-based paint wastewater using three types of activated carbon. Desalination and water treatment, 52, 2975-2986.

24. Fazal S., Zhang B., Zhong Z., Gao L., Chen X., 2015. Industrial wastewater treatment by using MBR (Membrane Bioreactor) Review study. Journal of Environmental Protection, 6, 584-598.

25. Keshmirizadeh E., Yousefi S., Rofouei M.K., 2011. An investigation on the new operational parameter effective in $\mathrm{Cr}$ (VI) removal efficiency: a study on electrocoagulation by alternating pulse current. Journal of Hazardous Materials, 190, 119-124.

26. Elhassadi A., 2008, Pollution of water resources from industrial effluents: a case study-Benghaz, Libya. Desalination, 222, 286-293.

27. El-kalyoubi M., Khallaf M.F., Abdelrashid A., Mostafa E.M., 2011. Quality characteristics of chocolate - containing some fat replacer. Annals of Agricultural Science, 56, 89-96.

28. Environmental Protection Agency, 1997. Wastewater treatment manuals primary, secondary and tertiary treatment, Ireland. ISBN 1899965467.

29. Ersahin M.E., Dereli R.K., Ozgun H., Donmez B.G., Koyuncu I., Altinbas M., Ozturk I., 2011. Source based characterization and pollution profile of a baker s yeast industry. Clean-Soil, Air, Water, 39, 543-548.

30. Esparza-Soto M., Arzate-Archundia O., Solís-Morelos C., Fall C., 2013. Treatment of a chocolate industry wastewater in a pilot-scale low-temperature UASB reactor operated at short hydraulic and sludge retention time. Water Science \& Technology, 67(6), 1353-1361.

31. García-Morales M.A., Juárez J.C.G., MartínezGallegos S., Roa-Morales G., Peralta E., del Cam- 
po López E.M., Barrera-Díaz C., Miranda V.M., Blancas T.T., 2018. Pretreatment of real wastewater from the chocolate manufacturing industry through an integrated process of electrocoagulation and sand filtration. International Journal of Photoenergy, 2146751, 1-7.

32. Gromiec M., Sadurski A., Zalewski M., Rowiński P., 2014. Threats related to water quality. Nauka 1,99122 (in Polish).

33. Hashemian S., Salari K., Yazdi Z.A., 2014. Preparation of activated carbon from agricultural wastes (almond Shell and orange peel) for adsorption of 2-pic from aqueous solution. Journal of Industrial and Engineering Chemistry, 20, 1892-1900.

34. Henze M., van Loosdrecht M.C.M., Ekama G.A., Brdjanovic D. (Eds.), 2008. Biological wastewater treatment: principles, modelling and design. ISBN: 9781843391883, IWA Publishing. London, UK.

35. Judd S., 2006. The MBR book: Principles and applications of membrane bioreactors in water and wastewater. London, England: Elsevier.

36. Kadirvelu K., Kavipriya M., Karthika C., Radhika M., Vennilamani N., Pattabhi S., 2003. Utilization of various agricultural wastes for activated carbon preparation and application for the removal of dyes and metal ions from aqueous solutions. Bioresource Technology, 87, 129-132.

37. Khan M., Mahmood T., Kalsoom U., Riaz M., Khan A.R., 2003. Characterization and treatment of industrial effluent from sugar industry. Journalchemical society of Pakistan, 25(3), 242-247.

38. Krzanowski S., Walega A., Pasmionka I., 2008. Wastewater treatment of selected food industry. Infrastruktura i Ekologia Terenów Wiejskich, 1, 1-89 (in Polish).

39. Lin H., Gao W., Meng F., Liao B.-Q., Leung K.-T., Zhao L., Chen J., Hong H., 2012. Membrane Bioreactors for Industrial Wastewater Treatment: A Critical Review. Critical Reviews in Environmental Science and Technology, 42(7), 677-740.

40. Liu Y., Xu H.-L., Yang S.-F., Tay J.-H., 2003. Mechanisms and models for anaerobic granulation in up flow anaerobic sludge blanket reactor. Water Research, 37, 661-673.

41. Mai Z., 2014. Membrane processes for water and wastewater treatment: study and modelling of interactions between membrane and organic matter. HAL. https://tel.archives-ouvertes.fr/tel00969165.

42. Marrot B., Barrios-Martinez A., Moulin P., Roche N., 2004. Industrial wastewater treatment in a membrane bioreactor: A review. Wastewater, 23(1), 59-68.

43. Mollah M.Y., Morkovsky P., Gomes J.A.G., Kesmez M., Parga J., Cocke D.L., 2004. Fundamentals, present and future perspectives of electrocoagula- tion. Journal of Hazardous Materials, 114(1-3), 199-210.

44. Mollah M.Y.A., Schennach R., Parga J.R., 2001. Electrocoagulation (EC) - science and applications. Journal of hazardous, 84(1), 29-41.

45. Mortula M., Shabani S., Rumaithi K.A., Nawaz W., Kashwani G., 2011. Removal of phosphorus and BOD from secondary effluent using coagulation. International Conference on Energy, Water and Environment.

46. Nayl A.E.A., Elkhashab R.A., El Malah T.,Yakout S.M., El-Khateeb M.A., Ali M.M.S., Ali H.M., 2017. Adsorption studies on the removal of COD and BOD from treated sewage using activated carbon prepared from date palm waste. Environmental Science and Pollution Research, 24, 22284-22293.

47. Ntuli F., Kuipa P.K., Muzenda E., 2011. Designing of sampling programmes for industrial effluent monitoring. Environmental Science and Pollution Research, 18, 479-484.

48. Ozgun H., Karagul N., Dereli R.K., Ersahin M.E., Coskuner T., Ciftci D.I., Ozturk I., Altinbas M., 2012. Confectionery industry: a case study on treatability-based effluent characterization and treatment system performance. Water Science \& Technology, 66(1), 15-20.

49. Paprowicz J.T., 1990. Activated carbons for phenols removal from wastewaters. Environ. Technol., 11, 71-82.

50. Parande A.K., Sivashanmugam A., Beulah H., Palaniswamy N., 2009. Performance evaluation of low cost adsorbents in reduction of COD in sugar industrial effluent. Journal of Hazardous Materials, 168, 800-805.

51. Park E., Enander R., Barnett S.M., Lee C., 2001. Pollution prevention and biochemical oxygen demand reduction in a squid processing facility. Journal of Hazardous Materials, 9, 341-349.

52. Phuong N.T.T., Tien T.T., Hoa P.T.T., Nam T.V., Luu T.L., 2018. Treatment of cake shop wastewater by pilot-scale submerged membrane bioreactor (SMBR). Bioresource Technology Reports, 4, 101-105.

53. Próba M., Wolny L., 2013. Industry and water environment. Chemia Przemysłowa, 4 (in Polish).

54. Qasim W., Mane A.V., 2013. Characterization and treatment of selected food industrial effluents by coagulation and adsorption techniques. Water Resources and Industry, 4, 1-12.

55. Ratajczak P., 2013. Membrane processes - introduction. Nauka i technika, 4, 16-20 (in Polish).

56. Regional Centre for Environmental Health Activities CEHA, 2006. A kompendium of standards for wastewater reuse in the Eastern Mediterranean Region.

57. Rajman A., 2007. Bioindication and impact on living organisms of sewage in the textile industry. 
Problemy Ekologii, 1(11), 41-46 (in Polish).

58. Rucka K., Balbierz P., Mańczak M., 2012. Assessment of the possibility of wastewater treatment from the confectionery industry. In: Traczewska T.M., (ed.), Interdisciplinary Issues in Engineering and Environmental Protection 2, Oficyna Wydawnicza Politechniki Wrocławskiej, Wrocław, 429-434 (in Polish).

59. Rucka K., Mańczak M., Balbierz P., 2014. Technological research of wastewater treatment from the confectionery industry using activated sludge. In: Traczewska T.M. and Kaźmierczak B. (eds), Interdisciplinary Issues in Engineering and Environmental Protection 4, Oficyna Wydawnicza Politechniki Wrocławskiej, 699-706 (in Polish).

60. Seghezzo L., Zeeman G., van Liel J.B., Hamelers H.V.M., Lettinga G., 1998. A review: The anaerobic treatment of sewage in UASB and EGSB reactors. Bioresource Technology, 65(3), 175-190.

61. Sahu O., 2017. Treatment of sugar processing industry effluent up to remittance limits: suitability of hybrid electrode for electrochemical reactor. MethodsX, 4, 172-185.

62. Sahu O., Mazumdar B., Chaudhari P.K., 2014. Treatment of wastewater by electrocoagulation: a review. Environmental Science and Pollution Research, 21(4), 2397-2413.

63. Sanou Y., Pare S., Baba G., Segbeaya K.N., BonziCoulibaly L.Y., 2016. Removal of COD in wastewaters by activated charcoal from rice husk. Revue des sciences de l'eau, 29(3), 265-277.

64. Scholz M., 2016. Activated sludge processes. Wetlands for Water Pollution Control, 15, 91-105.

65. Tanksali A.S., 2013. Treatment of sugar industry wastewater by upflow anaerobic sludge blanket reactor. International Journal of ChemTech Research, 5, 1246-1253.
66. Tchamango S., Nanseu-Njiki C.P., Ngameni E., Hadjiev D., Darchen A., 2010. Treatment of dairy effluents by electrocoagulation using aluminum electrodes. Science of the Total Environment, 408, 947-952.

67. Thirugnanasambandham K., Sivakumar V., Maran J.P., 2013. Optimization of electrocoagulation process to treat biologically pretreated bagasse effluent. Journal of Serbian Chemical Society, 5, 78613-78626.

68. US EPA, 1999. Wastewater Technology Fact Sheet Ozone Disinfection. Office of Water Washington, D.C., EPA 832-F-99-063.

69. Van der Bruggen B., Vandecasteele C., Van Gestel T., Doyen W., Leysen R., 2003. A review of pressure-driven membrane processes in process and wastewater treatment and in drinking water production. Environmental Progress, 22(1), 46-56.

70. Vanerkar A.P., Satyanarayan S., Satyanarayan S., 2013. Treatment of food processing industry wastewater by a coagulation/flocculation process. International Journal of Chemical and Physical Sciences, 2, 63-72.

71. Yakout S.M., Sharaf El-Deen G., 2016. Characterization of activated carbon prepared by phosphoric acid activation of olive stones. Arabian Journal of Chemistry, 9, 1155-1162.

72. Yamina G., Abdeltif A., Youcef T., Mahfoud H.D., Fatiha G., Lotfi B., 2013. A comparative study of the addition effect of activated carbon obtained from date stones on the biological filtration efficiency using sand dune bed. Energy Procedia, 36, 1175-1183.

73. Zulaikha S., Lau W.J., Ismail A.F., Jaafar J., 2013. Treatment of restaurant wastewater using ultrafiltration and nanofiltration membranes. Journal of Water Process Engineering, 2, 58-62. 